\title{
PERAN ORANG-ORANG TIONGHOA DALAM PEKABARAN INJIL: KAJIAN HISTORIS TERBENTUKNYA JEMAAT TIONGHOA DI JAWA BARAT
}

\author{
Yogi Fitra Firdaus \\ Sekolah Tinggi Teologi Bandung \\ yogifitra.firdaus@gmail.com
}

\begin{abstract}
Abstrak
Keberadaan gereja-gereja yang berlatar belakang Tionghoa di Indonesia tidak dapat dipisahkan dari pekerjaan misionaris yang dilakukan oleh penginjil Eropa atau penginjil Tionghoa. Meskipun memiliki peran besar dalam menyebarkan Injil, peran penginjil Tionghoa belum dibahas dengan baik, tidak seperti misionaris Belanda. Artikel ini mencoba menganalisis peran orang-orang Indonesia keturunan Tionghoa dalam penginjilan kepada sesama kelompok etnis mereka yang nantinya akan menjadi fondasi bagi gereja-gereja Tionghoa di Jawa Barat di era pra-kemerdekaan. Setidaknya ada enam tokoh yang memainkan peranan penting dalam proses pekabaran Injil di Indramayu, Batavia, Bandung dan Cirebon pada abad ke-19. Mereka bertindak sebagai perintis sekaligus pemimpin jemaat Tionghoa di kota-kota tersebut. Meskipun para pekabar Injil ini pertama kali mendengarkan tentang Yesus Kristus dari para misionaris Belanda, tetapi tidak dapat dikatakan bahwa kekristenan di kalangan masyarakat Tionghoa di Jawa Barat merupakan warisan zending Barat semata, karena jemaat-jemaat Tionghoa sudah terbentuk sebelum badan misi NZV datang ke Jawa Barat. Melalui artikel ini kita bisa mendapati kesamaan pola penginjilan juga mengetahui proses pertobatan serta alasanalasan orang Tionghoa di Jawa Barat beralih menjadi Kristen.
\end{abstract}

Kata kunci: Gereja Tionghoa; Misionaris Tionghoa; Penginjilan

\begin{abstract}
The existence of Chinese background-churches in Indonesia should not be separated from missionary work done by European evangelist or Chinese evangelist. Though having an immense role in spreading the gospel, the roles of Chinese evangelists are not yet well discussed, unlike Dutch missionaries. This article tries to analyze the role of Indonesian people of Chinese descent in evangelism to their fellow ethnic group that later on will be the foundation of Chinese churches in West Java in the pre-independence era. In the $19^{\text {th }}$ century, at least six Chinese evangelists played an important role in evangelism to their fellow ethnic in Indramayu, Batavia, Bandung, and Cirebon. They acted as pioneers and leaders of the Chinese churches. Although the Chinese evangelist came to know about Jesus Christ from the Dutch missionaries, it cannot be claimed that Christianity among the Chinese community in West Java just a legacy from the west, this is because Chinese churches were established even before NZV arrived at West Java. From this article, we can identify a similar strategy in evangelism and we can see the main reason why the Chinese people in West Java convert to Christianity.
\end{abstract}

Keywords: Chinese Churches; Chinese Missionary; Evangelism

\section{Pendahuluan}

Seperti halnya dengan gereja suku lainnya, gereja-gereja Tionghoa pun berkembang di Indonesia. Berdasarkan pengamatan penulis setidaknya ada 12 sinode gereja berlatar belakang Tionghoa dari berbagai denominasi yang menjadi anggota Persekutuan Gereja-gereja di Indonesia (PGI) seperti GMI, GKI, GK, GIA, GKMI, GKT, 
GKKB, GKKAI, GKKK, GKI-Sulsel, GKA dan GKY. ${ }^{1}$ Selain itu masih terdapat sinode GKBJ, Gepembri, GKPJ, GSRI, GKIm, Gepekris, GPMII, dll yang tidak bergabung dengan PGI, melainkan anggota dari Persekutuan Gereja-gereja Tionghoa di Indonesia (PGTI). Pendirian PGTI pada 29 Agustus 1998 menjadi penanda eksistensi gereja-gereja berlatar belakang Tionghoa tersebut. ${ }^{2}$

Keberadaan gereja-gereja Tionghoa itu, terkait erat dengan usaha pekabaran Injil sejak masa kolonialisme Barat di Indonesia. Sejalan dengan datangnya bangsa Eropa di Kepulauan Nusantara, kekristenan pun mulai diperkenalkan secara luas termasuk ke Jawa Barat. Muller Krugger meyakini bahwa orang-orang Portugis yang pertama kali membawa Injil ke negeri ini:

...di Indonesia tidak kita dapati sedikit pun bekas pekabaran Injil dan tidak terdapat seorang Kristen pun di Indonesia sebelum kedatangan Portugis pada abad ke-16. Merekalah yang pertama-tama menjadi penyiar agama Kristen di negeri ini. ${ }^{3}$

Meskipun ada pendapat yang menyatakan bahwa kekristenan sudah hadir di wilayah Barus (Sumatera Utara) pada abad ke-7 dan ke-12 melalui para penganut Nestorian, hal ini tidak cukup menjadi landasan keyakinan, bahwa pekabaran Injil sudah dilakukan pada masa itu. ${ }^{4}$ Mengenai itu Van den End berkata:

Tentang kedatangan orang-orang Kristen Nestorian ke Indonesia tidak ada kepastian, apalagi tentang jemaat-jemaat yang mungkin mereka dirikan. Yang pasti ialah bahwa tidak ada garis terus menerus (kontinuitas) antara mereka dengan kekristenan di Indonesia masa kini. ${ }^{5}$

Berdasarkan pernyataannya tersebut, Van den End tampak sependapat dengan Krugger bahwa para pekabar Injil Portugis-lah yang pertama kali berkarya di Nusantara pada abad ke-16. Sebab terdapat dokumen sejarah dan adanya kesinambungan yang nyata dengan kekeristenan di Indonesia hingga saat ini. ${ }^{6}$

Terlepas dari perbedaan pandangan mengenai kapan dan siapa yang membawa masuknya agama Kristen ke Indonesia, memang tidak dapat disangkal bahwa pekerjaan

\footnotetext{
1 “Gereja Anggota PGI - Website PGI,” diakses 28 November 2019, https://pgi.or.id/gereja-anggotapgi/.

2 “Sejarah,” PGTI, diakses 21 Januari 2020, https://pgti.co.id/page/12/sejarah.

${ }^{3}$ Muller Kruger, Sejarah Gereja Di Indonesia (Jakarta: BPK Gunung Mulia, 1966).17.

${ }^{4}$ Jonathan E. Culver, Sejarah Gereja Indonesia (Bandung: Biji Sesawi, 2014), 21.

${ }^{5}$ Th. van den End, Ragi Carita 1: Sejarah Gereja Di Indonesia 1500-1860 (Jakarta: BPK Gunung Mulia, 2006), 9.

${ }^{6}$ Ibid.
} 
misi di Indonesia berkembang setelah kedatangan bangsa Eropa, terutama pada masa pemerintahan Hindia-Belanda. Para zendeling utusan badan misi Belanda dan negaranegara Barat lainnya mulai bekerja di antara suku-suku di Nusantara tak terkecuali di Tanah Pasundan.

Menariknya sejarah misi kepada masyarakat Tionghoa di Jawa Barat tidak selalu diprakarsai oleh para misionaris Belanda. Orang-orang Tionghoa sendiri memiliki peran besar dalam mengabarkan berita keselamatan kepada sesamanya, bahkan membuahkan hasil yang banyak. Hal ini menepis anggapan bahwa kekristenan di Jawa Barat sematamata adalah warisan badan zending.

Para pekabar Injil Tionghoa tersebut, dianggap juga sebagai soko guru bagi beberapa jemaat di wilayah ini. Tetapi kiprah para pekabar Injil Tionghoa ini seolah terlupakan dan tidak banyak disinggung termasuk dalam kelas-kelas sejarah gereja di Indonesia. Selama penulis mengamati buku-buku sejarah gereja di Indonesia pun jarang sekali yang mengulas dari sisi ini. Maka untuk memahami pekabaran Injil kepada masyarakat Tionghoa di wilayah Pasundan, tulisan ini akan mengkaji secara historis berdasarkan sumber literatur, mengenai karya misi yang dilakukan oleh orang-orang Tionghoa sendiri. Sebagai cikal bakal terbentuknya jemaat-jemaat Tionghoa di Jawa Barat pada masa pra-kemerdekaan.

\section{Situasi Masyarakat Tionghoa di Jawa Barat pada Masa Kolonial}

Untuk mengetahui sejarah pekabaran Injil kepada masyarakat Tonghoa, maka perlu mengawalinya dengan melihat asal mula kedatangan etnis ini ke wilayah Nusantara sampai mereka membentuk suatu kelompok masyarakat dengan kebudayaan tersendiri. Keberadaan masyarakat Tionghoa di Nusantara, sudah terjadi sangat lama bahkan lebih tua dari usia Republik ini. Menurut catatan sejarah, relasi antara kerajaan-kerajaan di Nusantara dengan Kekaisaran Tiongkok telah berlangsung sejak masa Dinasti Han (206 SM - 24 M). ${ }^{7}$ Pada mulanya orang-orang Tionghoa yang datang ke Jawa tidak bermaksud untuk tinggal dan menetap, sebab tujuan kedatangan mereka adalah untuk penyelidikan, persahabatan serta perdagangan semata. Seperti yang dilakukan oleh Fahien, seorang biksu yang melakukan kunjungan ke Java Dvipa pada tahun 413 M untuk melihat "negara-

\footnotetext{
${ }^{7}$ Berdasarkan catatan perjalanan megarungi laut yang dilakukan oleh Chien Han Shu pada periode Dinasti Han, dapat diketahui telah terjadi hubungan antara Nusantara dan Tiongkok. Lih. Chris Hartono, Orang Tionghoa Dan Pekabaran Injil (Yogyakarta: Taman Pustaka Kristen, 1996), 1.
} 
negara Buddhis". ${ }^{8}$ Hal ini dapat dimaklumi sebab pada masa itu, baik Sumatera dan Jawa telah menjadi pusat perkembangan Buddhisme di Nusantara.

Hubungan Tiongkok dan Nusantara mencapai kemajuan pada masa Dinasti Ming, dengan perjalanan muhibah Laksamana Cheng Ho. Pada tahun 1412 armada Tiongkok itu mengunjungi Bintan, Bangka, Belitung, Karimata, Jawa, dan Madura. ${ }^{9}$ Kedatangan utusan kaisar Dinasti Ming pada abad ke-15 tersebut memantapkan hubungan diplomatik serta perdagangan antara Nusantara dengan Tiongkok. Hal ini mendorong lebih banyak lagi orang-orang Tionghoa untuk melakukan aktivitas ekonomi terutama dengan meningkatnya kebutuhan akan rempah-rempah dan porselen. Umumnya para pedagang tersebut datang dari wilayah Fujian dan Guandong. Meningkatnya hubungan perdagangan antara Tiongkok dan Nusantara ini membentuk kota-kota dagang di wilayah pesisir utara Jawa Barat seperti Banten dan Sunda Kelapa (Jakarta). ${ }^{10}$

Barulah pada masa VOC (Vereenigde Osst-Indische Compagnie), orang-orang Tionghoa datang dengan tujuan mencari nafkah dan menetap di kepulauan Nusantara. Situasi politik dan iklim yang kurang baik di daratan Tiongkok mendorong mereka untuk mencari peruntungan di Hindia Belanda. Mayoritas mereka tinggal di kota-kota pelabuhan seperti Banten dan Batavia. ${ }^{11}$ Seiring berjalannya waktu, jumlah penduduk Tionghoa semakin meningkat terutama pada saat Gubernur Jenderal J. P. Coen menjadikan Batavia sebagai pusat perdagangannya di tahun 1619. Coen melihat bahwa orang-orang Tionghoa telah mendominasi perdagangan, sehingga Coen berusaha mendatangkan lebih banyak lagi orang Tionghoa ke Batavia. Sebab peran ekonomi orang Tionghoa yang strategis dinilai dapat menguntungkan pemerintah VOC. ${ }^{12}$

Menurut Charles A. Coppel, menjelang tahun 1860 diperkirakan jumlah penduduk Tionghoa di wilayah Hindia Belanda mencapai 222.000 jiwa dan dua pertiganya tinggal di pulau Jawa. Tetapi pertumbuhan yang pesat terjadi bersamaan dengan meluasnya kekuasaan kolonial Belanda serta eksploitasi sumber-sumber kekayaan di kepulauan Indonesia, seperti yang tertera pada tabel $1 .^{13}$

\footnotetext{
${ }^{8}$ Hidajat Z.M meyakini bahwa Fa Hien adalah orang Tiongkok pertama yang berkunjung ke Pulau Jawa hal ini sesuai dengan catatan Fa Hien yang mengatakan bahwa tidak ada seorang pun orang Tiongkok yang tinggal di Jawa. Lih. Hidajat Z. M, Masyarakat Dan Kebudayaan Cina Indonesia (Bandung: Tarsito, 1993), 65.

${ }^{9}$ Ibid., 66.

${ }^{10}$ Chris Hartono, Ketionghoaan Dan Kekristenan (Jakarta: BPK Gunung Mulia, 1974). 19.

${ }^{11}$ Chris Hartono, Orang Tionghoa Dan Pekabaran Injil, 2.

${ }^{12}$ Darwin Darmawan, Identitas Hibrid Orang Cina (Yogyakarta: Penerbit Gading, 2014), 46.

${ }^{13}$ Charles A. Coppel, Tionghoa Indonesia Dalam Krisis (Jakarta: Sinar Harapan, 1994), 21-22.
} 
Tabel 1. Perkembangan Penduduk Tionghoa di Indonesia Pada Masa Pra-Kemerdekaan

\begin{tabular}{ccccccc}
\hline Tahun & Jawa & Sumatera & $\begin{array}{c}\text { Kalimantan } \\
\text { Barat }\end{array}$ & Lain-lain & $\begin{array}{c}\text { Luar } \\
\text { Jawa }\end{array}$ & $\begin{array}{c}\text { Jumlah } \\
\text { Total }\end{array}$ \\
\hline 1860 & 150.000 & - & - & - & 72.000 & 222.000 \\
1880 & 207.000 & 94.000 & 28.000 & 15.000 & 137.000 & 344.000 \\
1895 & 256.000 & 159.000 & 38.000 & 17.000 & 213.000 & 469.000 \\
1905 & 295.000 & 195.000 & 48.000 & 25.000 & 268.000 & 563.000 \\
1920 & 384.000 & 304.000 & 68.000 & 54.000 & 425.000 & 809.000 \\
1930 & 582.000 & 449.000 & 108.000 & 94.000 & 651.000 & 1.233 .000 \\
\hline
\end{tabular}

*Sumber: Charles A. Coppel

Data pada tabel 1 terlihat bahwa mayoritas masyarakat Tionghoa tinggal di pulau Jawa. Di Batavia sendiri hingga tahun 1920 terdapat 268.000 penduduk etnis Tionghoa. ${ }^{14}$ Setelah akhir abad ke-19 ketika semakin banyak pendatangan dari daratan Tiongkok ke Indonesia, terbentuk dua komunitas Tionghoa di Hindia Belanda yaitu Peranakan dan Totok.

\section{Peranakan}

Menurut Leo Suryadinata, sebelum akhir abad ke-19 orang-orang Tionghoa yang datang ke wilayah Nusantara didominasi oleh para laki-laki bujang yang belum memiliki istri atau yang meninggalkan istri mereka di daratan Tiongkok. Maka ketika sampai di Nusantara, mereka tinggal menetap dan menikah dengan para perempuan setempat sehingga tercipta pembauran budaya antara Tiongkok dengan budaya lokal. ${ }^{15}$ Keturunan dari pasangan inilah yang membentuk komunitas peranakan, mereka tidak lagi menguasai bahasa Mandarin dan hanya dapat berbicara bahasa daerah Indonesia.

Di pesisir utara Jawa — tempat dimana etnis Tionghoa tinggal—bahasa "Melayu pasar" berkembang sebagai lingua franca antara orang Tionghoa. Bahasa itu kemudian menjadi bahasa Melayu-Tionghoa yang pada dasarnya bahasa Melayu tetapi bercampur dengan istilah Hokkian. Sistem kekerabatan Fujian diterapkan dalam masyarakat peranakan dan sebutan Hokkian pun digunakan dalam keluarga. ${ }^{16}$

Adat istiadat Tionghoa mengalami penyesuaian dengan keadaan di Pulau Jawa. Pakaian peranakan merupakan kombinasi antara unsur Tionghoa dan Jawa, sampai akhir abad ke-19 kaum laki-laki masih menggunakan tengsha-baju panjang khas Tiongkokserta kopiah batok. Mereka tetap memelihara kuncir (taucang) dan menyapa dengan cara bersoja. Sedangkan perempuan peranakan menggunakan baju kebaya dan mengunyah sirih

\footnotetext{
${ }^{14}$ Darwin Darmawan, Identitas Hibrid Orang Cina, 43.

${ }^{15}$ Leo Suryadinata, Pribumi Indonesians, Chinese Minority, and China (Kuala Lumpur: Heinemann Educational Books, 1978), 86.

${ }^{16}$ Leo Suryadinata, "Negara Dan Minoritas Tionghoa Di Indonesia," WACANA 1, no. 2 (1999): 224. 
namun ketika menyapa mereka berjongkok seperti wanita Jawa. Anak-anak dibesarkan dalam budaya tersebut dan seluruh keluarga memeluk agama/ kepercayaan orang Tionghoa seperti pemujaan terhadap leluhur, menyimpan altar di rumah dan bersembahyang ke kelenteng. ${ }^{17}$ Keunikan budaya inilah yang membuat kaum peranakan terasing dari kelompok pendatang dari Tiongkok yang datang pada abad selanjutnya yang dinamakan golongan totok.

\section{Tionghoa Totok}

Golongan Totok baru datang ke wilayah Hindia Belanda pada awal abad ke-20 ketika seluruh Nusantara sudah dikuasi oleh pemerintah kolonial. Pada masa ini masuk para pendatang baru yang membawa serta keluarganya. Karena terhitung generasi pertama orang-orang Totok masih memelihara adat istiadat serta pola hidup seperti di tanah leluhurnya. Selain itu mereka juga masih berbicara dengan bahasa Mandarin atau dialek seperti Hokkian, Hakka, Konghu, Tiochiu, Hainan, Hok Chia, dll. ${ }^{18}$

Di dalam keseharian kaum Totok tidak bergaul dengan kelompok peranakan yang telah mengalami asimilasi dengan penduduk setempat. Menurut Chris Hartono, orangorang totok masih mempertahankan budayanya karena menganggap Hindia Belanda adalah persinggahan sementara untuk memperbaiki kehidupan. ${ }^{19}$ Artinya jika mereka sudah berhasil mengubah nasib, mereka akan kembali ke daratan Tiongkok.

Upaya mengembalikan kaum peranakan kepada akar budaya Tiongkok pernah dilakukan oleh golongan totok. Hal ini sejalan dengan munculnya nasionalisme Tionghoa melalui perkumpulan Tiong Hoa Hwee Koan (THHK) di Batavia. Di seluruh pelosok Hinda Belanda didirikan sekolah-sekolah berbahasa Mandarin yang bertujuan supaya masyarakat Tionghoa kembali mengenal budaya aslinya serta bersatu sebagai kelompok masyarakat yang dihormati oleh bangsa Belanda. ${ }^{20}$ Namun proses pengembalian tersebut tidak berhasil karena pemerintah kolonial Belanda membuka sekolah-sekolah berbahasa Belanda untuk anak-anak peranakan serta mencabut peraturan-peraturan yang tidak disukai kaum Tionghoa peranakan. Oleh sebab itu dalam sikap politiknya jika golongan totok

${ }^{17}$ Leo Suryadinata, 224. Mengenai kelenteng merupakan istilah khas orang Tionghoa di Indonesia dalam menyebut nama tempat ibadahnya yang diyakini berasal dari kata “Kwan Im Teng” (Kuil Kwan Im) ada juga menduga berasal dari bungi genta "teng-teng-teng" yang sering terdengar dari bangunan ini. Kelenteng tidak hanya berfungsi sebagai tempat persembahyangan tetapi juga pusat sosial dan kesenian. Lihat juga, M. Herwiratno, "Kelenteng: Benteng Terakhir dan dan Titik Awal Perkembangan Budaya Tionghoa di Indonesia," Jurnal LINGUA CULTURA 1, no. 1 (2007): 80.

${ }^{18}$ Chris Hartono, Orang Tionghoa Dan Pekabaran Injil, 3.

${ }^{19}$ Chris Hartono, Ketionghoaan Dan Kekristenan, 24.

${ }^{20}$ Leo Suryadinata, "Negara Dan Minoritas Tionghoa Di Indonesia," 225. 
berorientasi pada daratan Tiongkok maka kaum peranakan cenderung pada Hindia Belanda.

Keberadaan golongan Peranakan dan Totok ini berdampak juga dalam proses pekabaran Injil serta terbentuknya jemaat-jemaat berlatar belakang Tionghoa di Jawa Barat. Komunitas-komunitas Kristen Tionghoa yang muncul pada pertengahan hingga menjelang akhir abad ke-19 ini memang lebih banyak berasal dari golongan peranakan, hal ini dapat dikatakatan berkaitan erat dengan sikap politis serta pencarian status sosial mereka di tengah masyarakat.

\section{Kepercayaan Masyarakat Tionghoa}

Seperti telah disebutkan pada bagian sebelumnya bahwa para pendatang asal Tiongkok ini terdiri dari berbagai suku dan dialek seperti Hokkian, Hakka, Konghu, Tiochiu, Hainan, Hok Chia, dll. Tidak hanya bahasa, mereka pun tetap mempertahankan tradisi dan kepercayaan asli mereka yang disebut Sam Kauw yaitu Konfusianisme, Taoisme dan Buddhisme. ${ }^{21}$ Biasanya dalam kepercayaan itu ditambah juga dengan pemujaan kepada tokoh-tokoh tertentu yang dianggap sebagai dewa atau dewi.

Di antara ketiga kepercayaan itu, Konfusianisme lebih berpengaruh dan mendarah daging dalam kehidupan orang Tionghoa. Sebab ajaran ini telah dianut lebih dari dua ribu tahun lamanya. Hariyono dalam bukunya menyatakan:

Selama masa dinasti Han (205 SM - 220 M) ajaran Konfusius praktis telah menjadi ajaran agama negara. Dalam tahun 130 SM ajaran itu dinyatakan sebagai ilmu dasar dalam pendidikan pejabat-pejabat pemerintah, dan merupakan suatu pola yang pada dasarnya masih berlanjut sampai berdirinya Republik Tiongkok pada tahun $1912 .^{22}$

Pada dasarnya ajaran Konfusianisme mengajarkan tentang moralitas yang harus dimiliki oleh setiap manusia sesuai dengan konsep "Hau". Dengan demikian, maka "Hau" lah yang menjadi dasar, baik dalam kehidupan keluarga maupun masyarakat dan negara. ${ }^{23}$ Konsep ini yang dipakai oleh Konfusius untuk mengatur tatanan sosial masyarakat.

Dalam perkembangan selanjutnya, "Hau" tidak hanya dipahami dalam hubungan keluarga atau masyarakat, tetapi juga antara orang hidup dengan para nenek moyangnya. ${ }^{24}$ Menurut orang Tionghoa pengabdian terhadap orangtua termasuk kepada para leluhur yang

\footnotetext{
${ }^{21}$ Chris Hartono, Orang Tionghoa Dan Pekabaran Injil, 12.

${ }^{22}$ P. Hariyono, Kultur Cina Dan Jawa (Jakarta: Sinar Harapan, 1993), 19.

${ }^{23}$ Chris Hartono, Orang Tionghoa Dan Pekabaran Injil, 13.

${ }^{24}$ Ibid,.
} 
telah meninggal adalah sesuatu yang penting, sehingga mereka ada dalam kesempurnaan hidup. Hal ini melahirkan tradisi penyembahan terhadap nenek moyang yang tentunya dilandasi oleh kepercayaan bahwa hubungan antara orangtua dan anak tidak diputuskan oleh kematian. ${ }^{25}$ Menurut Gondomono aspek penyembahan terhadap nenek moyang tersebut melekat pada kehidupan masyarakat Tionghoa, termasuk dalam siklus kelahiran, pernikahan, dan kematian. ${ }^{26}$

Jika orang-orang Tionghoa tidak melakukan hal demikian, maka dianggap sebagai orang yang "Put Hau" ${ }^{27}$ Istilah "Put Hau" ini berkaitan dengan konsep kebahagiaan serta keselamatan, oleh sebab itu masyarakat Tionghoa terutama para laki-laki sangat patuh dan setia dalam menyembah nenek moyangnya. Sehingga salah satu hambatan dari orang Tionghoa, khususnya para laki-laki ketika akan memeluk Kristen adalah kewajiban mereka untuk memimpin penghormatan kepada arwah para leluhur serta keterikatan terhadap tradisi. Karena yang membentuk identitasnya sebagai orang Tionghoa adalah pemeliharaan terhadap tradisi religius dan sosial mereka.

\section{Gambaran Umum Pekabaran Injil pada Masyarakat Tionghoa di Masa VOC}

Pemerintah VOC sebetulnya tidak terlalu menaruh minat dalam karya misi di wilayah kekuasannya. Menurut Adolf Heukeun, VOC dan para pegawainya yang datang ke Batavia semata-mata untuk mencari kekayaan. ${ }^{28}$ Meskipun demikian penyebaran agama Kristen kepada suku-suku di Nusantara tetap menjadi perhatian para pendeta Belanda yang sebetulnya didatangkan untuk merawat kerohanian para pegawai VOC serta budak-budak Kristen yang tergabung dalam De Protestantsche Kerk in Nederlandsch-Indie (Gereja Protestan di Hindia Belanda/ GPI). ${ }^{29}$ Tetapi misi tersebut belum terarah kepada masyarakat Tionghoa, padahal hingga tahun 1739 terdapat 4.368 orang Tionghoa di dalam kota Batavia dan 10.574 di luar kota. ${ }^{30} \mathrm{Hal}$ ini terbukti dengan tidak adanya penginjil yang fasih berbahasa Tionghoa.

\footnotetext{
25 Ibid., 14.

${ }^{26}$ Gondomono, Membanting Tulang Menyembah Arwah (Jakarta: Pustaka Firdaus, 1996), 30.

27 Secara sederhana "Put Hauw" berarti orang-orang yang tidak patuh, tidak taat dan tidak mengabdi kepada nenek moyanya. Lih. Chris Hartono, Orang Tionghoa Dan Pekabaran Injil, 15.

${ }^{28}$ Adolf Heukeun, Gereja-Gereja Tua Di Jakarta (Jakarta: Cipta Loka Caraka, 2003), 43.

${ }^{29}$ Sejumlah anggota GPI yang tidak puas dengan pembatasan itu mendirikan Lembaga Pekabaran Injil ke dalam dan ke luar (GIUZ). Badan misi ini memprakarsai atau mendukung pekabaran injil kepada penduduk Batavia yang belum Kristen, tokoh pendiri GIUZ yang terkenal adalah F. L. Anthing dan E. W. King. Lih. Th. van den End dan J. Weitjens, Ragi Carita 2: Sejara Gereja Di Indonesia 1860-an - Sekarang (Jakarta: BPK Gunung Mulia, 2003), 219.

${ }^{30}$ Darwin Darmawan, Identitas Hibrid Orang Cina, 46.
} 
Kehadiran Justus Hernius di Batavia pada 17 Juli 1624, sedikit membangkitkan harapan bagi Pekabaran Injil kepada komunitas Tionghoa di pusat pemerintahan VOC itu. Selain menguasai bidang pengobatan Hernius juga mahir berbahasa Tionghoa. ${ }^{31}$ Sehingga ia mampu menerjemahkan pengakuan iman rasuli, kesepuluh firman, doa Bapa Kami, dan ringkasan katekismus ke dalam bahasa Tionghoa. ${ }^{32}$ Sayangnya pekerjaan Hernius ini tidak berlangsung lama dan tidak membuahkan hasil, sebab pekerjaannya itu tidak mendapatkan dukungan dari pemerintah VOC yang lebih mementingkan urusan niaga ketimbang usaha pekabaran Injil. ${ }^{33}$ Bahkan hingga kepindahannya ke Saparua, karya dari Justus Hernius tidak pernah ada tindak lanjut.

Usaha pekabaran Injil kepada masyarakat Tionghoa kembali menemukan gairahnya dengan kehadiran London Missionary Society (LMS) ketika Nusantara dikuasai oleh Inggris. LMS melihat penginjilan kepada orang-orang Tionghoa di Nusantara sebagai batu loncatan untuk melakukan penginjilan kepada masyarakat di Tiongkok. William Milne menjadi misionaris LMS pertama yang bekerja di Pulau Jawa. ${ }^{34}$ Sebenarnya Milne tidak berniat datang ke negeri ini, ia diutus oleh LMS untuk melakukan pekabaran Injil ke Tiongkok. Namun, karena terhambat izin masuk Milne memutuskan untuk melayani orang-orang Tionghoa di Batavia antara tahun 1818-1822.

Sepeninggal Milne, pelayanan kepada orang-orang Tionghoa dilanjutkan oleh Henry Medhurst. Ia melakukan penginjilan kepada masyarakat Tionghoa selama 21 tahun (1822-1843). ${ }^{35}$ Menurut catatan sejarah, Medhurst adalah orang yang paling giat mengabarkan Injil kepada orang-orang Tionghoa sampai ke Bali dan Kalimantan. Tetapi karya Medhurst ini juga tidak membuahkan jemaat-jemaat Tionghoa yang mapan.

Dengan berakhirnya masa penjajahan Inggris yang singkat itu, Belanda kembali menjajah Nusantara. Bersamaan dengan hal tersebut, di Eropa sedang mengalami gairah penginjilan kepada suku-suku di wilayah koloni Eropa, akibat pengaruh gerakan Pietisme. ${ }^{36}$ Maka berdirilah berbagai lembaga zending untuk membawa orang-orang kepada Yesus Kristus. Di Jawa Barat sendiri badan zending melakukan pelayanan yaitu

\footnotetext{
${ }^{31}$ Chris Hartono, Ketionghoaan Dan Kekristenan, 80.

${ }^{32}$ Muller Kruger, Sejarah Gereja Di Indonesia, 196.

${ }^{33}$ Chris Hartono, Ketionghoaan Dan Kekristenan, 80.

${ }^{34}$ Ibid,.

35 Ibid., 81.

${ }^{36}$ Pengaruh Pietisme pada gerakan pekabaran injil dimulai pada abad ke-18 dan semakin besar ketika
} memasuki abad ke-19. Orang-orang Pietis ini yang menyadari bahwa pekabaran injil kepada bangsa yang belum mengenal Kristus adalah tugas gereja yang sangat penting. Lih. Christian de Jonge, Gereja Mencari Jawab: Kapita Selekta Sejarah Gereja (Jakarta: BPK Gunung Mulia, 2016), 42. 
Nederlandse Zending Vereeniging (NZV) lembaga ini yang di kemudian hari melakukan pelayanan kepada orang-orang Tionghoa juga khususnya di Jawa Barat.

\section{Pekabaran Injil kepada Masyarakat Tionghoa di Jawa Barat}

Sampai menjelang akhir abad ke-19, tanah Pasundan masih menjadi wilayah yang belum ditaburi oleh Injil, sebab pemerintah Hindia Belanda khawatir akan timbulnya perlawanan dari orang-orang Sunda yang sudah menganut Islam. ${ }^{37}$ Maka pada saat utusan NZV pertama tiba di tahun 1863 dan ingin memulai pekabaran Injil di tengah suku Sunda, mereka terhambat izin dari pemerintah setempat. Setelah menteri jajahan di Negeri Belanda turun tangan, barulah Pdt. C. Albers dapat bekerja di Cianjur (10 Juli 1865), sedangkan kedua rekannya yaitu Pdt. A. Djikstra sudah terlebih dahulu ke Cirebon (1863) dan Pdt. C. Linden di Indramayu (1864). ${ }^{38}$ Izin pekabaran Injil di pesisir utara Jawa Barat memang jauh lebih mudah karena ditempati juga oleh suku Jawa.

Karya misi NZV di Jawa Barat pada waktu itu hanya difokuskan kepada suku Sunda saja. Namun, orang-orang Sunda ternyata tidak terlalu terbuka terhadap Injil, sebab kekristenan diasosiasikan sebagai agama "urang Walanda" yang artinya agama bangsa penjajah. Walaupun dalam kurun waktu 60 tahun NZV telah mengutus sekitar 40 orang pekabar Injil ke wilayah ini tetapi tidak berhasil membangun jemaat Sunda yang kokoh seperti di wilayah lain. ${ }^{39}$ Kramer menggambarkan Jawa Barat sebagai tanah yang tandus seperti yang ia tulis dalam laporannya sebagai berikut:

Karena Tanah Pasundan ternyata merupakan sebuah padang gurun rohaniah. Para pekabar Injil menawarkan Injil kepada mereka. Mereka secara pribadi mengalami betapa mencekam hati bila sekelompok besar penduduk dengan membisu dan tidak acuh menyatakan sikapnya: "Kami tidak meminta kalian, tidak meminta pula pemberian kalian. ${ }^{40}$

H. J. Rooseboom, mantan direktur NZV pun memberikan kesaksiannya bahwa "Terdapat banyak perlawanan di Jawa Barat, memang disana terdapat banyak penentang di

${ }^{37}$ J. D. Wolterbeek, Babad Zending Di Pulau Jawa (Yogyakarta: Taman Pustaka Kristen, 1995), 139. Menurut Kraemer peraturan ini justru membuat wilayah Jawa Barat semakin tertutup terhadap Injil, bandingkan Muller Kruger, Sejarah Gereja Di Indonesia, 192.

${ }^{38}$ Para utusan pertama NZV itu tiba pada 5 Januari 1863, Pdt. C. Albers harus menanti selama 2.5 tahun hingga diperbolehkan bekerja di Priangan. Lih. Th. van den End dan J. Weitjens, Ragi Carita 2 : Sejarah Gereja Di Indonesia 1860-an - Sekarang, 221.

${ }^{39}$ Ibid., 222.

${ }^{40}$ Chris Hartono, Orang Tionghoa Dan Pekabaran Injil, 33. 
antara orang-orang Islam dan juga di antara orang-orang kafir." ${ }^{41}$ Bagi penulis orang-orang kafir yang dimaksud oleh Rooseboom adalah para penganut animisme.

Meskipun bukan sasaran pekabaran Injil, hasil yang menggembirakan justru hadir dari kalangan Tionghoa peranakan di pesisir utara Jawa Barat. ${ }^{42}$ Ketika Pdt. van der Linden datang ke Indramayu, ia mendapati adanya Jemaat Tionghoa di kota itu. ${ }^{43}$ Keberadaan orang-orang Tionghoa Kristen di Indramayu bermula dari perjumpaan Ang Boen Swi dengan Pdt. J. A. W. Kroll di Cirebon. Sebelum pulang, Pdt. Kroll yang membekali Ang Boen Swi sebuah Alkitab berbahasa Jawa yang dibacanya terus secara berulang-ulang. Hingga suatu ketika ia berkata "Inilah emas tulen yang telah lama saya mencarinya." Lantas Ang Boen Swi menceritakan tentang "emas tulen" itu kepada keluarga-keluarga Tionghoa lainnya, maka pada tanggal 13 Desember 1858 keluarga Ang Boen Swi beserta tiga keluarga lainnya menerima baptisan kudus. ${ }^{44}$

Pada tahun 1856 seorang penginjil dari Tiongkok bernama Gan Kwee didatangkan ke Pulau Jawa oleh F. L. Anthing pendiri Genootschap voor In -en Uitwendige Zending (GIUZ) untuk melakukan penginjilan kepada orang-orang Tionghoa di Batavia dan mendirikan Jemaat Patekoan pada tahun $1868 .{ }^{45}$ Setelah beberapa lama Gan Kwee melayani di Batavia, ia mulai mengabarkan Injil ke kota-kota lain. Di Cirebon Gan Kwee berjumpa dengan Yoe Ong Pauw yang akhirnya memberi diri dibaptis. Yoe Ong Pauw giat mengabarkan Injil kepada masyarakat Tionghoa di Cirebon dan menjadi cikal bakal berdirinya Jemaat Tionghoa di Cirebon. ${ }^{46}$

Jemaat-Jemaat Tionghoa di beberapa tempat berkembang dengan cepat seperti di Batavia, Indramayu, Cirebon, Bandung bahkan ke Sukabumi dan Bogor. ${ }^{47}$ Hal tersebut mendorong NZV untuk mengarahkan pekerjaannya kepada orang-orang Tionghoa di Jawa Barat. Menyaksikan buah-buah pekabaran injil itu, A. K. de Groot mengatakan:

${ }^{41}$ Aslinya "Er is zoovel tegenstand op West Java - zegt een ande. Zonder twijfel, er zinj daar vele tegenstanders. Maar waar zijn deze niet? Ze zijn er in de Mohammedanansche, ze zijn e rook in de Heidenwereld." Lih. Ibid., 33.

${ }^{42}$ Pekabaran injil kepada orang-orang Tionghoa pada masa kolonial Belanda memang dapat dikatakan terlambat. Badan Zending Belanda lebih memprioritaskan "suku-suku setempat”, baru pada 26 Maret 1929 didirikan Badan Misi “Chinese Foreign Mission Union” oleh R.A Jaffray, Leland Wang, Tzau Liu Thang dan Hwang Yen Tsu di Guanxi, Tiongkok. Badan misi ini khusus melayani orang-orang Tionghoa di Asia Tenggara termasuk wilayah Hindia-Belanda. Lih. Jenny Wongka, trans., Sejarah 70 Tahun CFMU (Chinese Foreign Mission Union) 1929-1999 (Tiga Sinode Ex CFMU, 1999), 10.

43 J. D. Wolterbeek, Babad Zending Di Pulau Jawa, 139.

${ }^{44}$ Chris Hartono, Orang Tionghoa Dan Pekabaran Injil, 23.

${ }^{45}$ Th. van den End dan J. Weitjens, Ragi Carita 2: Sejara Gereja Di Indonesia 1860-an - Sekarang, 223.

${ }^{46}$ Chris Hartono, Orang Tionghoa Dan Pekabaran Injil, 28.

${ }^{47}$ Pada tahun 1882 dibaptiskan orang Tionghoa pertama di Sukabumi atas nama Tjoa Beng Yang sedangkan pekabaran injil kepada masyarakat Tionghoa di Bogor baru terjadi pada tahun 1888/1889. Lih. Muller Kruger, Sejarah Gereja Di Indonesia, 197. 
"Sejarah telah membuktikan kepada kita bahwa Allah kadangkala telah bekerja dengan cara yang ajaib di antara orang-orang Tionghoa. Jemaat Injili Patekoan (Batavia), Indramayu, dan Kudus telah membuktikan hal itu, bahwa tanpa pekabar-pekabar Injil Eropa Allah juga berkenan membiarkan Injil berakar di hati orang-orang Tionghoa....,"48

Secara insani Kraemer mengatakan bahwa jemaat-jemaat Tionghoa telah menjadi unsur penyelamat bagi pekerjaan NZV di Jawa Barat yang telah nyaris putus asa. ${ }^{49}$ Baik di Indramayu, Batavia, Cirebon maupun Bandung terbentuknya kelompok jemaat Tionghoa ternyata diprakarsai oleh orang-orang Tionghoa sendiri, mereka memainkan peran yang sangat penting dalam mengabarkan injil kepada sesamanya hingga terbentuknya jemaatjemaat mandiri.

\section{Peran Orang-Orang Tionghoa dalam Pekabaran Injil}

Seperti yang sudah disinggung sebelumnya bahwa jemaat-jemaat berlatar Tionghoa di Jawa Barat terbentuk atas kiprah dari para pekabar Injil Tionghoa sendiri. Meskipun para perintis jemaat ini dibaptiskan oleh para pendeta Belanda, namun mereka yang bergiat melakukan pekabaran injil baik melalui penginjilan keliling maupun pertemuan di rumahrumah. Setidaknya ada enam tokoh pekabar Injil Tionghoa yang memainkan peran sangat besar di Jawa Barat.

1. Ang Boen Swi dan Ang Dji Gwan di Indramayu

Kota Indramayu terletak di sekitar lembah Cimanuk yang pada masa lalu terkenal dengan pelabuhannya. Keberadaan jemaat Tionghoa di kota ini bahkan jauh sebelum kedatangan badan misi NZV ke Jawa Barat memang cukup mengherankan. Apalagi di pertengahan abad ke-19, masyarakat Tionghoa belum menjadi sasaran pekabaran Injil.

Jemaat Tionghoa di Indramayu dirintis oleh Ang Boen Swi dan puteranya. Seperti lazimnya orang Tionghoa, sebelum mengenal kekristenan Ang Boen Swi adalah seorang yang taat akan kepercayaan leluhurnya, selain itu ia juga dikenal rajin melakukan adat istiadat setempat. Tetapi hal tersebut tidak memberikan kedamaian baginya, terutama kepastian akan kehidupan setelah kematian. ${ }^{50}$

\footnotetext{
${ }^{48}$ Chris Hartono, Orang Tionghoa Dan Pekabaran Injil, 23-24.

${ }^{49}$ Ibid., 35.

${ }^{50}$ Ibid., 21.
} 
Perjumpaan Ang Boen Swi dengan kekristenan bermula dari perbincangannya dengan Pdt. J. A. W. Kroll yang kala itu sedang membaca Alkitab. ${ }^{51}$ Dengan penuh rasa penasaran, Ang Boen Swi bertanya mengenai buku yang sedang dibaca oleh orang Belanda itu, maka Pdt. Kroll menerangkan secukupnya tentang agama Kristen dan keselamatan yang dibawa oleh Yesus Kristus. Sebelum kembali ke Indramayu, Ang Boen Swi dipinjami Alkitab Perjanjian Baru dalam bahasa Jawa. Alkitab yang terus dibaca berulang-ulang hingga ia menemukan "emas tulen yang selama ini dicarinya." 52

Memang tidak banyak catatan yang mengulas mengenai proses pertobatan Ang Boen Swi di Indramayu. Mengutip buku Peringatan 100 Tahun GKI Djabar Indramaju 1858-1958 dan tulisan zendeling S. Coolsma dalam De Zendingseeuw voor Nederlandsch Oost-Indië, Chris Hartono meyakini bahwa sebelum memutuskan menjadi Kristen Ang Boen Swi mengalami pergulatan teologis terlebih dahulu terutama mengenai konsep keselamatan dalam agama lamanya. Bagi Ang Boen Swi, kepercayaan Tionghoa seperti pemujaan terhadap dewa-dewi dan leluhur tidak memberikan jaminan keselamatan akan kehidupan kekal. Mengenai hal ini Hartono menuliskannya demikian:

Ang Boen Swi adalah seseorang yang hidup dalam dosa-dosanya dan yang menyebabkan hidup dalam ketakutan terhadap kepastian masa depannya (kehidupan kekal). Karena itu, ia berusaha mencari kesentausaan dan kedamaian yang diharapkannya dapat menjadi pegangan bagi kepastian masa depannya tersebut. Dengan perkataan lain, ia berusaha mencari keselamatan hidupnya. Untuk maksud itulah-untuk cukup waktu yang lama-ia melakukan "pengembaraan": ia mempelajari ajaran "agama" Tionghoa... Namun ia tidak menemukan apa yang dicarinya. Kemudian ia membaca Alkitab Perjanjian Baru dan melakukan penyelidikan terhadapnya. Akhirnya ia menemukan apa yang dicarinya, yaitu berita Injil tentang keselamatan manusia, yang kemudian disebut emas yang tulen itu. ${ }^{53}$

Kita dapat melihat bahwa perpindahan keyakinan Ang Boen Swi menjadi Kristen melewati suatu proses yang cukup panjang. Sebagai orang Tionghoa, dia berusaha mempelajari dan menghayati agama sebelumnya termasuk mendalami ujaran-ujaran pujangga Tiongkok kuno, bahkan ia sempat juga mempelajari agama Islam. ${ }^{54}$ Tetapi hanya di dalam kekristenan Ang Boen Swi menemukan jaminan akan hidup yang kekal. Dengan demikian, dapat dikatakan bahwa alasannya menjadi Kristen dikarenakan menemukan keselamatan dalam Yesus Kristus.

${ }^{51}$ Pdt. J. A. W Kroll adalah pendeta Indische Kerk yang melayani jemaat Belanda di Cirebon. Lih. Th. van den End dan J. Weitjens, Ragi Carita 2: Sejara Gereja Di Indonesia 1860-an - Sekarang, 223.

${ }^{52}$ Chris Hartono, Orang Tionghoa Dan Pekabaran Injil, 22.

53 Ibid., 41.

54 Ibid., 21. 
Pergulatan ini juga sempat dialami oleh Ang Dji Gwan anak laki-lakinya. Pada mulanya ia sangat menentang keras Ang Boen Swi untuk berubah keyakinan menjadi seorang Kristen. Nampaknya sebagai laki-laki Tionghoa, Ang Dji Gwan memahami betul konsep "Hau" harus dipraktikkan dengan melakukan penyembahan kepada leluhur khususnya oleh seorang kepala keluarga atau anak laki-laki. Jika keluarganya menjadi Kristen maka tidak ada lagi yang sembahyang kepada nenek moyang dan akan mendatangkan kutukan ("Put Hau"). Tetapi hal ini tidak berlangsung lama, karena Ang Boen Swi berhasil mengajak seluruh anggota keluarganya termasuk Ang Dji Gwan. Dalam pandangan penulis, tentunya Ang Boen Swi bisa meyakinkan puteranya itu akan jaminan keselamatan dalam Yesus Kristus.

Selain keluarganya sendiri, terdapat juga beberapa keluarga lain yang ikut dalam "penelahan Alkitab" di Indramayu. Setelah dirasa siap maka pada tanggal 13 Desember 1858 dilayankan sakramen Baptis oleh Pdt. J. A. W. Kroll kepada 19 orang Tionghoa di Indramayu. Terdiri dari 6 orang anggota keluarga Ang Boen Swi, 4 orang anggota keluarga Lauw Pang, 7 orang keluarga Lie Hong Leng dan 2 orang dari keluarga Tjie Tek. ${ }^{55}$ Peristiwa pembaptisan itu menandai lahirnya kelompok jemaat Tionghoa pertama di Jawa Barat.

Tampak bahwa alasan-alasan spiritual menjadi motivasi orang-orang Kristen Tionghoa generasi pertama di Indramayu. Seperti kesaksian Tan Ki An yang menjadi Kristen karena meyakini kebenaran Alkitab. Bagi Tan Ki An yang rajin mengikuti kelompok penelaahan, melalui berita Alkitab itu ia memiliki relasi yang akrab dengan Yesus Kristus dan dapat merasakan hadirat-Nya, sehingga tidak merasa hidup sendirian. ${ }^{56}$ Tan Ki An mendapati bahwa Yesus Kristus bukanlah pribadi yang jauh seperti dewa-dewa di kahyangan.

Selanjutnya apa yang dialami oleh Liem Keng Ho dan Ong Boegel, memiliki kesamaan dengan Ang Boen Swi. Baik Lim Keng Ho dan Ong Boegel menyadari bahwa dirinya adalah manusia berdosa terutama setelah mengikuti pertemuan penelaahan Alkitab. Mereka menemukan kasih dan keselamatan dalam diri Yesus Kristus yang telah menebus dosa-dosa mereka. Liem Keng Ho berucap, "Yesus telah mengasihi aku. Aku akan lebih dekat dengannya supaya aku dapat mengenalnya dengan lebih baik". Kemudian Ong Boegel yang memiliki dua istri (poligami) berujar, "Dahulu aku menyatakan bahwa beristri

\footnotetext{
55 Ibid., 22-23.
}

56 Ibid., 42. 
dua tidaklah jahat. Tetapi sekarang aku celik bahwa aku sebenarnya berada di bawah cengkeraman si Jahat". 57

Memang tidak dapat dipungkiri bahwa pada perkembangan selanjutnya ada juga orang-orang Tionghoa yang menjadi Kristen karena alasan politis dan pencarian status sosial di tengah masyarakat. Kekristenan selalu diasosiasikan dengan agama penguasa, kepercayaan orang Barat yang dalam hal ini adalah Bangsa Belanda. Bagi sebagian orang Tionghoa yang tinggal di Jawa Barat, kebudayaan Eropa itu memiliki prestise dan kehormatan yang tinggi. ${ }^{58}$ Oleh sebab itu jika menjadi Kristen akan memiliki posisi yang terhormat dan secara politik dapat mengidentifikasikan dirinya dengan kaum penguasa yaitu Belanda. Apalagi dengan diberlakukannya pemisahan golongan seperti Eropa dan Indo-Eropa, Timur Asing, dan Pribumi membuat sebagian orang Tionghoa tidak memilih agama yang membuatnya turun kelas "menjadi setara" dengan kaum pribumi.

Baik Ang Boen Swi dan Ang Dji Gwan senantiasa melakukan pekabaran Injil kepada orang-orang Tionghoa di sekitar Indramayu. Bahkan pada saat Pdt. J. L. Zeger, utusan NZV melayani di Indramayu, Ang Dji Gwan diangkat sebagai asisten pendeta. ${ }^{59}$ Seperti pada saat pertama kali terbentuk, Ang Boen Swi dan puteranya itu membuka rumah mereka untuk kebaktian, pekabaran Injil dan penelahan Alkitab. Suatu kegiatan yang berhasil menarik banyak orang Tionghoa kepada injil. ${ }^{60}$ Apa yang dilakukan oleh kedua orang tersebut, telah menginspirasi Tan Ki An untuk membuka rumahnya juga bagi pekabaran injil kepada orang Tionghoa di Indramayu.

Orang-orang Tionghoa Kristen di Indramayu dikenal sebagai kelompok masyarakat yang berkarakter baik, murah hati dan bersedia membantu. Sikap itu diperlihatkan oleh Tan Ki An yang tidak hanya menarik orang-orang Tionghoa tetapi juga berhasil memperkenalkan kekristenan kepada masyarakat Suku Sunda dan Suku Jawa di daerah Tamiyang serta Juntikebon. ${ }^{61}$ Hingga masa kini jemaat rintisan Ang Boen Swi masih tetap berdiri dan menjadi gereja berlatar belakang Tionghoa paling tua di Jawa Barat.

\section{Gan Kwee dan Gouw Kho di Batavia}

Pada tahun 1856 GIUZ berhasil mendatangkan seorang penginjil dari Tiongkok ke Batavia bernama Gan Kwee. Hal ini sesuai dengan pandangan F. L. Anthing salah satu

\footnotetext{
${ }^{57}$ Ibid., 42-43.

${ }^{58}$ Ibid., 45.

${ }^{59}$ J. D. Wolterbeek, Babad Zending Di Pulau Jawa, 139.

${ }^{60}$ Chris Hartono, Orang Tionghoa Dan Pekabaran Injil, 22.

${ }^{61}$ Ibid., 24.
} 
pendiri badan misi itu yang menyatakan bahwa "Pekabaran Injil kepada orang Tionghoa harus dilakukan oleh tenaga Tionghoa sendiri." ${ }^{62}$ Gan Kwee dikenal sebagai orang yang menguasai adat dan kepercayaan Tionghoa sehingga berguna dalam karya misinya.

Karena mampu berbahasa serta mengenal budaya Tionghoa, Gan Kwee dapat diterima oleh masyarakat Tionghoa di Batavia, sehingga tahun 1868 pekerjaannya membuahkan hasil dengan dibaptiskan 17 orang dewasa yang menjadi anggota mula-mula dari jemaat Patekoan. ${ }^{63}$ Namun, karena kurang tenaga rohani dan adanya persoalan terkait adat Tionghoa dan keyakinan Kristen, jemaat ini belum berkembang secara jumlah. Selain itu Gan Kwee sering meninggalkan Batavia untuk melakukan penginjilan kepada orangorang Tionghoa di kota lain seperti Cirebon, Tegal, Semarang, Ambarawa, Salatiga, Surakarta, Magelang, Pasuruan, dan Probolinggo.

Pada saat Gan Kwee berkeliling itulah, secara praktis kepemimpinan jemaat Patekoan dipegang oleh Gouw Kho-seorang pedagang Kristen asal Tiongkok yang menetap di Batavia sejak 1874. Gouw Kho memegang peran penting dalam menjalankan roda pelayanan di jemaat tersebut, sedangkan para zendeling dari Java Comite (JC) hanya bertindak sebagai rekan sekerja dan penasihat dari Gouw Kho. ${ }^{64}$

Selama melayani di Patekoan, Gouw Kho giat melakukan pekabaran Injil kepada sesama orang Tionghoa. Ia memberikan waktu, tenaga, dan pikiran demi perluasan karya misi di Batavia, bahkan menghibahkan sebidang tanah dan empat buah rumah demi perkembagan jemaat. $^{65}$ Maka dapat dilihat bahwa orang Tionghoa tidak hanya mempersembahkan tenaga tetapi juga harta demi pekabaran Injil.

Segala tindakan Gouw Kho mendorong orang-orang Kristen lain di Patekoan untuk memberitakan Injil kepada masyarakat Tionghoa. Pekabaran Injil seolah menjadi jati diri dari jemaat ini, hal tersebut nampak dari nama yang dipilih oleh yaitu Evangelishe Chineesche Gemeente tot Uitbreiding van Gods Koninkrijk. ${ }^{66}$

Jumlah jemaat semakin bertambah pada saat kedatangan penginjil Dr. John Sung dari Tiongkok. Selama 3 hari John Sung mengadakan KKR di Gereja Sion (sekarang GPIB Sion). Pada masa-masa itu banyak orang Tionghoa yang menerima Injil dan percaya kepada Yesus Kristus, sehingga jemaat Patekoan membaptis 150 orang petobat baru. ${ }^{67}$ Meskipun perkembangan kuantitas anggota jemaat di Patekoan baru terjadi setelah

\footnotetext{
${ }^{62}$ Ibid., 29.

${ }^{63}$ Darwin Darmawan, Identitas Hibrid Orang Cina, 36.

${ }^{64}$ Chris Hartono, Orang Tionghoa Dan Pekabaran Injil, 25.

${ }^{65}$ Ibid,.

${ }^{66}$ Ibid., 26.

${ }^{67}$ Darwin Darmawan, Identitas Hibrid Orang Cina, 38.
} 
memasuki abad 20, tetapi karya Gan Kwee dan Gouw Kho di abad ke-19 memiliki pengaruh yang sangat besar atas keberadaan jemaat Tionghoa di Batavia itu.

\section{Thung Goan Hok di Bandung}

Pada tahun 1732-1852, diterapkan aturan kartu pas untuk memasuki kawan Bandung. Aturan ini tidak hanya berlaku bagi orang Eropa tetapi juga orang Tionghoa, oleh sebab itu baru setelah tahun 1852 orang-orang Tionghoa mulai berdatangan serta menetap di kota ini. ${ }^{68}$ Namun hingga masa itu, masyarakat Tionghoa belum menjadi sasaran penginjilan dari badan misi Belanda.

Thung Goan Hok menjadi orang Tionghoa pertama yang dibaptiskan di Bandung. Ia pertama kali mendengar pemberitaan Injil dari para zendeling NZV yang bekerja di Bandung. Setelah meyakini bahwa Yesus Kristus adalah Juruselamatnya, Thung Goan Hok menerima sakramen baptis oleh Pdt. A. de Haan pada 9 Desember $1888 .{ }^{69}$ Peristiwa itu menjadi tonggak sejarah terbentuknya jemaat Tionghoa dan membawa pengaruh luar biasa bagi pekabaran Injil di antara orang-orang Tionghoa di Bandung.

Setelah menjadi orang Kristen, Thung Goan Hok mulai membuka rumahnya di Jl. Gardu Jati 51A dan menyediakan ruangan untuk perkumpulan pekabaran Injil. Karena dilakukan oleh orang Tionghoa, maka banyak orang Tionghoa lain yang tertarik mengikuti perkumpulan Injil itu. ${ }^{70}$ Perkumpulan Injil yang diprakarsai dan dipimpin oleh Thung Goan Hok itu menghasilkan buahnya dengan dibaptiskan 17 orang dewasa dan anak-anak pada tahun $1889 .{ }^{71}$ Thung Goan Hok beserta ketujuhbelas orang itu pada hakikatnya adalah cikal bakal dari jemaat Tionghoa di Bandung.

Menjadi sebuah catatan penting, meskipun Thung Goan Hok mengenal Injil dari para zendeling NZV, namun secara formal NZV baru mengutus tenaga misinya bagi orang Tionghoa di Bandung pada tahun 1920. ${ }^{72}$ Maka dari itu dapat dipastikan bahwa antara kurun waktu 1888-1920, pekabaran Injil dilakukan oleh orang-orang Tionghoa sendiri. Selain Thung Goan Hok, orang-orang Kristen Tionghoa lain yang giat mengabarkan Injil adalah Tan Goan Tjong, Gouw Gwan Jang dan The Tee Bie. Mereka mengabarkan Injil

${ }^{68}$ Tri Hiantoro dkk., 85 Tahun GKI Kebon Jati 121 Tahun Awal Sejarah Gereja (Bandung: Panitia Perayaan HUT Ke 85 GKI Jl. Kebon Jati 100, 2009), 5.

${ }^{69}$ Chris Hartono, Orang Tionghoa Dan Pekabaran Injil, 26.

${ }^{70}$ Tri Hiantoro dkk., 85 Tahun GKI Kebon Jati 121 Tahun Awal Sejarah Gereja, 5.

${ }^{71}$ Chris Hartono, Orang Tionghoa Dan Pekabaran Injil, 27.

${ }^{72}$ Ibid,. 
hingga ke wilayah lain di Jawa Barat seperti Cimahi, Cianjur, Tasikmalaya, Garut, dan Cirebon dan menghasilkan buah yang banyak pula. ${ }^{73}$

Hingga pada tahun 1920, orang-orang Tionghoa dimasukan ke dalam jemaat Sunda di Jl. Kebon Jati 46. Tetapi setelah jumlah anggota Tionghoa semakin banyak maka timbul keinginan untuk membentuk jemaat sendiri. Hal ini bukan hanya karena perbedaan bahasa antara orang Tionghoa dan orang Sunda melainkan juga ada istiadat. Oleh sebab itu pada Maret 1924 dibentuklah Kerkraad (Majelis Gereja) Tionghoa pertama yang terdiri dari Tan Djin Gie, Tan Kim Tjiang, Tan Goan Tjong, Hong To Bin, Hong Han Keng, Tan Tjok Lim, Lie Kok Man, Lim Djong Sin, dan Pdt. Lasschuit sebagai ketuanya. ${ }^{74}$ Maka sejak tahun 1924 secara resmi berdiri gereja Tionghoa di Bandung.

\section{Yoe Ong Pauw di Cirebon}

Sebagaimana ulasan di atas bahwa Gan Kwee sering meninggalkan Batavia untuk melakukan pekabaran Injil kepada orang-orang Tionghoa di kota lainnya termasuk Cirebon. Seperti yang dinyatakan oleh A. Djikstra seorang zendeling NZV dalam kesaksiannya "Untuk pertama kalinya saya berjumpa dengan Gan Kwee. Tiga tahun lalu ia juga berkunjung ke Cirebon. Dari benih Injil yang ditaburkan di situ, ia dapat melihat beberapa hasilnya yang baik., ${ }^{, 75}$

Salah satu buah dari pekerjaan Gan Kwee di Cirebon adalah Yoe Ong Pauw seorang letnan Tionghoa di kota itu, sebuah jabatan yang diberikan oleh pemerintah Hindia Belanda sebagai pemimpin masyarakat Tionghoa. Mengingat posisinya yang terhormat dan strategis di kalangan masyarakat Tionghoa, tentunya proses pertobatan Yoe Ong Pauw bukan tanpa tantangan. Menjadi seorang Luitenant der Chinezent, Yoe Ong Pauw tidak hanya berperan dalam lingkup sosial kemasyarakatan namun juga keagamaan, sebab pada umumnya Kelenteng tempat peribadatan orang Tionghoa didirikan oleh para Letnan Tionghoa itu. ${ }^{76}$ Menjadi Kristen artinya harus siap jikalau sewaktu-waktu kehilangan posisi terhormat di tengah masyarakat Tionghoa di Cirebon. Penulis tidak mendapatkan informasi kapan Yoe Ong Pauw menerima sakramen baptis, hanya terdapat catatan yang menyatakan bahwa ia dibaptis oleh zendeling A. Djikstra. ${ }^{77}$

\footnotetext{
73 Ibid,

${ }^{74}$ Tri Hiantoro dkk., 85 Tahun GKI Kebon Jati 121 Tahun Awal Sejarah Gereja, 6.

${ }^{75}$ Chris Hartono, Orang Tionghoa Dan Pekabaran Injil, 31.

${ }^{76}$ M. Herwiratno, "Kelenteng: Benteng Terakhir Dan Titik Awal Perkembangan Budaya Tionghoa Di Indonesia," Jurnal LINGUA CULTURA 1, no. 1 (2007): 79.

${ }^{77}$ Chris Hartono, Orang Tionghoa Dan Pekabaran Injil, 28.
} 
Ada kesamaan pola dengan apa yang dilakukan oleh Ang Boen Swi di Indramayu dan Thung Goan Hok di Bandung, Yoe Ong Pauw juga membuka rumahnya untuk perkumpulan pekabaran Injil. Usahanya itu membawa hasil yang menggembirakan karena banyak mendapatkan perhatian serta kunjungan dari orang-orang Tionghoa yang akhirnya memberi diri dibaptis. ${ }^{78}$ Keluarga Yoe Ong Pauw bersama orang-orang Tionghoa lainnya itu yang menjadi cikal bakal berdirinya jemaat Tionghoa di Cirebon. Selain Yoe Ong Pauw masih ada orang-orang Tionghoa lain yang menjadi pekabar Injil kepada sesamanya seperti Tjan Soen Kie dan The Tee Kwie. Bahkan putera dari Tjan Soen Kie yaitu Tjang Hong Jauw menjadi pekabar Injil di daerah Senen (Batavia). ${ }^{79}$ Di dalam proses pekabaran Injil kepada masyarakat Tionghoa di Cirebon dapat ditemukan hal yang sama seperti di kota lainnya bahwa pekabaran Injil banyak dilakukan oleh orang-orang Tionghoa sendiri, tidak hanya itu pola dan strateginya pun memiliki kemiripan.

\section{Kesimpulan}

Orang-orang Tionghoa memiliki peranan penting dalam pekabaran Injil kepada sesama orang Tionghoa di Jawa Barat, bahkan itu terjadi sebelum badan misi Eropa menaruh perhatian kepada kelompok masyarakat ini. Kesamaan etnis, budaya serta penguasaan bahasa Tionghoa memungkinkan pekerjaan misi ini lebih dapat diterima oleh masyarakat Tionghoa. Kendatipun para pekabar Injil Tionghoa itu pertama kali mendengar kekristenan dari para misionaris Belanda, perlu diperhatikan bahwa karya misi dan perintisan jemaat selanjutnya banyak dilakukan oleh orang-orang Tionghoa sendiri. Mereka tidak hanya bertindak sebagai pekabar Injil tetapi juga pemimpin jemaat sepeti yang kita temukan dari tokoh Ang Boen Swi, Ang Dji Gwan, Gan Kwee, Gouw Kho, Thung Goan Hok, dan Yoe Ong Pauw. Para zendeling NZV nampaknya lebih banyak berperan sebagai pendamping dan pelayan sakramen dari jemaat-jemaat yang baru lahir itu.

Apabila diperhatikan maka ada kesamaan pola dan strategi yang dilakukan oleh para pekabar Injil Tionghoa itu diantaranya yaitu dilakukan oleh orang Tionghoa sendiri, menggunakan perkumpulan Injil di rumah-rumah, pekabaran Injil keliling hingga ke kotakota lain, dan adanya pelipat gandaan artinya dari satu orang pekabar Injil akan menghasilkan pekabar-pekabar Injil Tionghoa lainnya. Hal yang paling penting adalah bahwa pekabaran Injil itu dilakukan oleh kaum awam. Nampak dengan jelas adanya

\footnotetext{
78 Ibid,.

${ }^{79}$ Ibid, 29.
} 
pergerakan misi dan keterlibatan orang-orang, dalam mengabarkan Injil keselamatan dari Tuhan Yesus Kristus yang semestinya tetap dipelihara hingga masa kini.

Meskipun para pekabar Injil itu memiliki jasa besar dalam terbentuknya jemaatjemaat Tionghoa di Jawa Barat, tetapi kiprah mereka seringkali terlupakan. Terlihat dari sedikitnya sumber literatur sejarah gereja Indonesia yang mengangkat kisah tentang mereka. Oleh sebab melalui kajian historis ini diharapkan dapat mengingatkan kembali bahwa gereja Tionghoa bukanlah warisan dari zending Belanda semata, ada peran orangorang Tionghoa juga dalam mengenalkan kekristenan di Indonesia negeri ini. Hal ini sekaligus menjadi upaya untuk membangkitkan kembali pergerakan misi kaum awam pada gereja-gereja di Indonesia.

\section{Kepustakaan}

Coppel, Charles A. Tionghoa Indonesia Dalam Krisis. Jakarta: Sinar Harapan, 1994.

Culver, Jonathan E. Sejarah Gereja Indonesia. Bandung: Biji Sesawi, 2014.

Darmawan, Darwin. Identitas Hibrid Orang Cina. Yogyakarta: Penerbit Gading, 2014.

End, Th. van den. Ragi Carita 1: Sejarah Gereja Di Indonesia 1500-1860. Jakarta: BPK Gunung Mulia, 2006.

End, Th. van den, and J. Weitjens. Ragi Carita 2: Sejara Gereja Di Indonesia 1860-an Sekarang. Jakarta: BPK Gunung Mulia, 2003.

“Gereja Anggota PGI - Website PGI.” Diakses 28 November 2019. https://pgi.or.id/gerejaanggota-pgi/.

Gondomono. Membanting Tulang Menyembah Arwah. Jakarta: Pustaka Firdaus, 1996.

Hariyono, P. Kultur Cina Dan Jawa. Jakarta: Sinar Harapan, 1993.

Hartono, Chris. Ketionghoaan Dan Kekristenan. Jakarta: BPK Gunung Mulia, 1974. Orang Tionghoa Dan Pekabaran Injil. Yogyakarta: Taman Pustaka Kristen, 1996.

Herwiratno, M. "Kelenteng: Benteng Terakhir Dan Titik Awal Perkembangan Budaya Tionghoa Di Indonesia.” Jurnal LINGUA CULTURA 1, no. 1 (2007).

Heukeun, Adolf. Gereja-Gereja Tua Di Jakarta. Jakarta: Cipta Loka Caraka, 2003.

Hiantoro, Tri, Jotje H. Karuh, Heru Setiawan, and David Roestandi. 85 Tahun GKI Kebon Jati 121 Tahun Awal Sejarah Gereja. Bandung: Panitia Perayaan HUT Ke 85 GKI Jl. Kebon Jati 100, 2009.

Jonge, Christian de. Gereja Mencari Jawab: Kapita Selekta Sejarah Gereja. Jakarta: BPK Gunung Mulia, 2016.

Kruger, Muller. Sejarah Gereja Di Indonesia. Jakarta: BPK Gunung Mulia, 1966.

M, Hidajat Z. Masyarakat Dan Kebudayaan Cina Indonesia. Bandung: Tarsito, 1993.

PGTI. “Sejarah.” Diakses 21 Januari 2020. https://pgti.co.id/page/12/sejarah. 
Suryadinata, Leo. "Negara Dan Minoritas Tionghoa Di Indonesia." WACANA 1, no. 2 (1999).

Pribumi Indonesians, Chinese Minority, and China. Kuala Lumpur: Heinemann Educational Books, 1978.

Wolterbeek, J. D. Babad Zending Di Pulau Jawa. Yogyakarta: Taman Pustaka Kristen, 1995.

Wongka, Jenny, trans. Sejarah 70 Tahun CFMU (Chinese Foreign Mission Union) 19291999. Tiga Sinode Ex CFMU, 1999. 